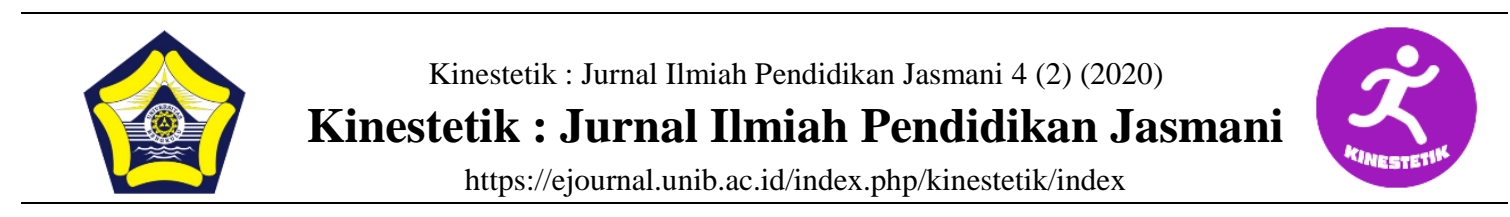

\title{
THE EFFECTIVENESS OF THE LET'S EXERCISE FUNDAMENTAL MOVEMENT SKILLS MODEL ON CHILDREN WITH MILD INTELLECTUAL DISABILITYS IN SPECIAL NEED EDUCATION OF PALEMBANG
}

\author{
Selvi Atesya Kesumawati ${ }^{1}$, Husni Fahritsani ${ }^{2}$, Novri Asri $^{3}$, Endang Pratiwi ${ }^{4}$ \\ ${ }^{1}$ Sport Education, Universitas Bina Darma, Palembang, Indonesia \\ ${ }^{2}$ Sport Education, Universitas PGRI, Palembang, Indonesia \\ ${ }^{34}$ Sport Education, Universitas Islam Kalimantan Muhammad Arsyad Al Banjari, Banjarmasin, Indonesia
}

Info Artikel

Article History:

Received September 2020

Revised September 2020

Accepted September 2020

Available online September 2020

Keywords:

model, playing, movement

\begin{abstract}
This study aims to produce and test the effectiveness of the fundamental movement skills (FMS) learning model product, let's exercise on students with mild intellectual disability (ID) in primary special need education (SDLB) Palembang City. This research took place in 2018 before the pandemic Covid-19 era. The subjects of the small group trial were 10 students and 4 teachers, and the subjects for the large group trial were 23 students and 4 teachers for grade 1 in 3rd SDLB serving children with ID in Palembang City. The data analysis technique used the $\mathrm{z}$ test effectiveness test (parameter) and the Wilcoxon test (non parameter). The results showed that the large group trial data for aspects of basic movement skills, cognitive abilities, pleasure (fun), and focus of attention obtained an average value of trial 2 greater than trial 1 , as well as the $\mathrm{z}$-count value of the lets exercise model of play activity is greater. from the z-table value (1.96), so the difference is significant. So it can be concluded that the game model lets exercise be effective for improving FMS, cognitive abilities, pleasure, and focus on attention of grade 1 students with mild ID in SDLB.
\end{abstract}

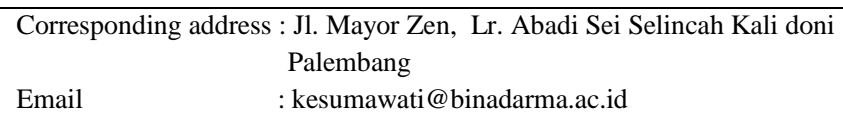

Email
ISSN 2685-6514 (online)

ISSN 2477-331X (print)

DOI : $10.33369 /$ jk.v4i2.12528 


\section{INTRODUCTION}

Children with intellectual disabilities (ID) are children who have an IQ below the average of normal children, but for children with mild ID, from a physical aspect, at a glance, it is the same as other normal children. In most cases, children with ID are detected after entering school based on the results of an IQ test which is an indicator of a person's intellectual level.

ID are evidenced in children by low levels of intellectual functioning and adaptive behavior problems, with an onset before age 18" (Allen \& Cowdery, 2015; Schalock et al., 2010). "Adaptive behaviors include the three domains of conceptual skills; language, number skills, language, social skills; e.g., interpersonal skills, self-esteem, social responsibility, and practical skills; e.g., personal care, occupational skills"(Astramovich et al., 2015), Several developmental theories state that exercise, experience, motivation and the social environment greatly influence a person's adaptive ability.

Many children with learning disabilities do not have any gross motor problems and are actually quite athletic. Some famous athletes who had learning disabilities include Olympic gold medalist Bruce Jenner, basketball star Magic Johnson, football star Dexter Manley, and baseball star Pete Rose "(Angle, 2007). "However, some children with learning disabilities have motor problems, not surprisingly, motor problems are most notable in children with motor and sensory-related learning problems such as dyspraxia and visual processing problems"(Shapiro, 2001; (Payne, 2017). "Persons with mild disabilities show few obstacles in terms of motor skills in childhood. These small delays occur in movement, balance, agility and in carrying out daily activities (daily life activities, games, work"(Zikl et al., 2013). "Children with ID, because of particular biological/genetic causes, often have physical anomalies that lead to specific and more pronounced motor delays and deficits. This is perhaps most notable in children with Down syndrome, a genetic disorder that causes pervasive developmental delays(Pueschel, 2000). Among many other issues, children with Down syndrome have hypoto- nia (low muscle tone), increased flexibility in joints, decreased muscle strength, and medical problems such as heart and respiratory problems, all of which"(Payne, 2017).

Adaptive physical education is a form of service provided by formal special need education (SLB) with the aim of developing movement skills for children with special needs, therefore physical educators need to understand the effect of reflexes and reactions on motor development milestones and motor skills learning. Physical educators need to understand the effect of reflexes and reactions on motor development and learning motor skills, In addition, the teacher must understand the concept of packaging learning that is in accordance with the characteristics and provides a 
pleasant experience of movement for students with special needs.

Playing is an activity that is liked by children, including children with special needs. Play is considered a central component of healthy growth through which children develop cognition, language, social competence, self-regulation, and self-esteem(Frost, 2010). Dillman Taylor and Bratton (2014) suggested that play be viewed holistically as an important part of children's social-emotional, cognitive, and neurological development. Beginning in infancy, children participate in a variety of play behaviors, including object play, physical play, pretend or dramatic play, constructive play, and games with rules (Frost, Wortham, \& Reifel, 2012). The play activities of children may be conceptualized along a developmental continuum that corresponds with cognitive development" (McCabe, Jenkins, Mills, Dale, \& Cole, 1999; (Astramovich et al., 2015).

Play increases brain development and growth, establishes new neural connections, and in a sense makes the player more intelligent. It improves the ability to perceive others' emotional state and to adapt to everchanging circumstances. Play is more frequent during the periods of most rapid brain growth. Because adult brains are also capable of learning and developing new neural circuits, adults also continue to play"(Goldstein, 2012). "Play theorist Brian Sutton-Smith believes that the human child is born with a huge neuronal over-capacity, which if not used will die. 'Not only are children developing the neurological foundations that will enable problem solving, language and creativity, they are also learning while they are playing. They are learning how to relate to others, how to calibrate their muscles and bodies and how to think in abstract terms. Through their play children learn how to learn. What is acquired through play is not specific information but a general mind set towards solving problems that includes both abstraction and combinatorial flexibility where children string bits of behaviour together to form novel solutions to problems requiring the restructuring of thought or action... A child who is not being stimulated, by being ... played with, and who has few opportunities to explore his or her surroundings, may fail to link up fully those neural connections and pathways which will be needed for later learning"'Sutton-Smith 1997).(Goldstein, 2012).

According to research conducted in homes, the two most powerful factors related to cognitive development during infancy and the preschool years are the availability of play materials and the quality of the mother's involvement with the child"(Goldstein, 2012). "The availability of toys in infancy is related to the child's IQ at three years of age. Children with access to a variety of toys were found to reach higher levels of intellectual achievement, regardless of the children's sex, race, or social class (Bradley 1985, Elardo 1975).In one study, the availability of toys intended 
for social play increased social interaction by disabled children in an inclusive preschool"(Driscoll 2009);(Goldstein, 2012).

Physical abilities of children with ID, especially those related to coordination and strength, are still below the average of normal children, whereas muscle strength is the ability to work muscles to withstand a load, so there are basic mechanical elements that play a role in muscle strength, Chan (2012) continued. describes strength or strength, that is an ability of the human physical condition that is needed to increase the learning achievement of motion. This is the most basic and very important component in sports, considering that strength is the driving force of any physical activity that plays a role in preventing injury and is a basic component of other components of physical condition. This muscle strength is needed in performing movements such as: pulling, throwing, repelling, pushing and lifting (Hardiyono et al., 2019).

Physical education develops the body's strength, promotes physical well-being, and provides opportunities for the early physical development of body awareness, spatial awareness, and safety.

Each student should be enabled to experience physical activities safely and to explore a wide range of stimulating equipment, to the full extent of his/her capacity and with as much help as is necessary(Disabilities, n.d.) Gross motor skills are very essential to our daily lives. Everymovement of our body requires some form of gross motor skill. And soit is important that children are given the opportunity to reachtheir full potential. "Children with intellectual disabilities often have psychological problems associated with carrying out ex- ercise. Moreover, their experience of exercise is limited. Health problems accompanying obesity are also more frequent in children with intellectual disabilities" (Balakrishnan; (Hayakawa \& Kobayashi, 2011).

$\begin{array}{ccc}\text { People with intellectual } \\ \text { disabilities } & \text { (ID) face tremendous }\end{array}$ disparities in health status, health care access, and all-cause morbidity and mortality." Many health issues common to people with ID are related to lifestyle behaviors such as diet and physical activity. Despite what is known about the value of moderate to vigorous physical activ- ity (MVPA), few people with ID participate in physical activity at a sufficient frequency, duration, or intensity to yield health benefits"(Lohrmann, 2012). "Adults with intellectual disabilities have high rates of physical inactivity and related chronic diseases. Researchers have called for an increase in the development and evaluation of health education programs adapted to the unique needs of this population. Formative and process evaluation strategies were applied to develop a physical activity education program. The first phase of formative evaluation included a comprehensive literature review to select educational strate- gies and curriculum content"(Bodde et al., 2012). 
The importance of increasing physical activity can be considered even greater in the case ofpersons with intellectual and multiple disabilities, given that these persons engage in lower levels of physical activity than their typical counterparts and tend to have comparatively larger health concerns (Bartlo and Klein, 2011; Dixon-Ibarra et al., 2016; Queralt et al., 2016; Woodmansee et al., 2016;"'(Lancioni et al., 2018). The results of observations made by researchers in mentally disabled children in SDLB C Karya Ibu Palembang, found that physical growth did not experience interference even as normal children in general, but had difficulty in learning new things, especially those related to motion, children still looked stiff, less beautiful to looked at, and disproportionate when making movements (Kesumawati et al., 2019).

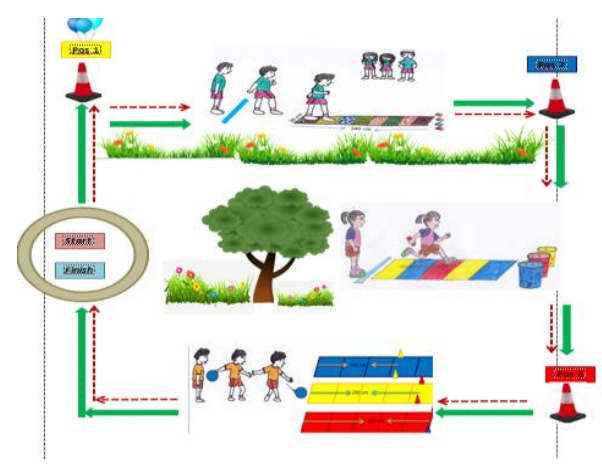

Fig 1. Game Model Let's Exercise

Based on the background of the problem and the researchers' preliminary studies, the researchers developed a fundamental movement learning model for children with ID, the model according to the theme of the 2013 curriculum. The theme of the game in this study is "Let's Excercise". This model consists of 3 game posts, each post has a task of movement and different media and equipment. The objectives to be achieved in this game are (fig 1): (1) Improve straight forward movement skills; (2) Improve running skills as fast as possible; (3) Improves ball rolling skills; (4) Improve cognitive abilities, pleasure and focus attention.

\section{METHODS}

Research and learning models can be in the form of procedural models expressed by Borg and Gall (2003: 570). This study aims to develop a motion learning model for children with mild ID using the Borg and Gall R\&D model. According to Borg and Gall (1989), R\&D research in education includes ten steps, namely: (1) Research and Information colletion, (2) Planning, (3) Develop Preliminary form of Product, (4) Preliminary Field Testing, (5) Main Product Revisions, (6) Main Field Trials, (7) Operational Product Revisions, (8) Operational Field Tests, (9) Final Product Revisions, and (10) Dissemination and Implementation. The data instrument test in the learning model trial allows small-scale and widescale trial using a checklist with a rubric; FMS aspect, cognitive aspect, pleasure aspect and focus attention aspect. The data analysis technique used in this study was the Wilcoxon different test ( $\mathrm{z}$ test) quantitative analysis technique.

\section{Sampling Procedures}

Small-scale trial subjects were 10 students and 4 teachers at 1st class in primary special need education for 
children with mild ID (SLBC) Karya Ibu Palembang, 23 students and 4 teachers in all three SLBs in Palembang City (SLB C Karya Ibu, SLB B Negeri Pembina and SLB C YPAC).

\section{Materials and Apparatus}

The instrument used in this study was a checklist using a rubric, consists of 4 aspects, namely movement skills, cognitive abilities, pleasure and focus attention, each aspect has an assessment guideline, the highest score is 4 and the lowest score is 1 .

\section{Procedures}

This research was conducted in 2018 before the Covid-19 pandemic era. After the validity test has been carried out by the expert and declared valid, followed by validity and reliability testing, then continued with small group trials and product revisions, the next stage is large group trials, in this journal the researcher only presents data on the effectiveness test of the motion learning model lets exercise on large group trials.

\section{Data Analysis}

Data analysis techniques to test the effectiveness of the lets exercise motion learning model product use the $\mathrm{z}$ test (if the data is normally distributed) and Wilcoxon (if the data is not normally distributed). The following is the test data for the effectiveness of the lets exercise FMS learning model;
Table 1. Table of Results Effectiveness Test Large Group Trial

Trial FMS Aspect Cognitive Aspect Pleasure Aspect Focus Attention Aspect

\begin{tabular}{|c|c|c|c|c|c|}
\hline A & Z & A & Z & A & Z \\
\hline & & A & Z & & \\
\hline 1 & 7,9 & 3,461 & 8 & 3,944 & 8,5 \\
\hline & 2,64 & $8 \quad 7,7$ & & & \\
\hline 2 & 9,1 & & 9 & & 9,1 \\
\hline & & & 9 & & \\
\hline Ztabel & 1,96 & & 1,96 & & 1,96 \\
\hline & & & 1,96 & & \\
\hline
\end{tabular}

\section{RESULT}

The results of the analysed of the difference test of learning models in large group trials for aspects of FMS, cognitive abilities, fun, and focus of attention obtained an average value of trial 2 greater than trial 1 , as well as the $\mathrm{z}$-calculated value of the learning model lets exercise is greater than the z-table value (1.96), so the difference is significant. So it can be concluded that the lets exercise game model is effective for increasing FMS, cognitive abilities, pleasure, and focus attention of children with mild ID student grade 1 SDLB.

\section{DISCUSSION}

Each person's motor skills differ due to several factors among others; interest or will, age and experience. The process learning movement which is commonly known as motor learning consists of several stages, namely the 
cognitive stage, the associative stage and the autonomous stage(Ringan, 2019). Children with ID have intellectual and social and behavioral barriers, but children with ID also have the same opportunities as normal children in order to optimize their mobility so they can live independently and minimize help from others. This research needs to be given to children with ID both in the context of formal education at school and non-formal education in the family environment

\section{CONCLUSION}

The let's excercise learning model that has been developed is suitable for use by Physical Education teachers in SDLB or parents or families who have children with ID while still accompanying them while playing to increase self-confidence.

\section{ACKNOWLEDGEMENT}

Learning sports and health physical education has a very important role in providing learning experiences for students, because students will be directly involved in systematic learning experiences through physical activities, sports games that are carried out systematically, directed and planned to encourage physical growth. , psychological development, FMS and motor skills, knowledge and reasoning, appreciation of values and habituation to a healthy lifestyle. FMS learning in playing activities in physical education learning at SDLB C is an effort to assist teachers in developing FMS material which is expected to stimulate and increase FMS and student as provisions in carrying out daily life.

\section{REFERENCES}

Arofah, P. (2018). ANALISIS KESULITAN DALAM BELAJAR PENDIDIKAN JASMANI OLAHRAGA DAN KESEHATAN (PJOK) KELAS III SEKOLAH INKLUSIF SD NEGERI 5 ARCAWINANGUN PURWOKERTO TAHUN PELAJARAN 2017/2018 (Doctoral dissertation, Universitas Peradaban).

Astramovich, R. L., Lyons, C., \& Hamilton, N. J. (2015). Play Therapy for Children With Intellectual Disabilities. Journal of Child and Adolescent Counseling, 1(1), 27-36. https://doi.org/10.1080/23727810.201 5.1015904

Bodde, A. E., Seo, D. C., Frey, G. C., Lohrmann, D. K., \& van Puymbroeck, M. (2012). Developing a physical activity education curriculum for adults with intellectual disabilities. Health Promotion Practice, 13(1), 116-123.

https://doi.org/10.1177/152483991038 1698

Disabilities, G. L. (n.d.). Physical Education Guidelines for Teachers of Students with.

Goldstein, J. (2012). Play in Children' $S$ Development, Health and WellBeing. February.

Hardiyono, B., Pratama, B. A., \& Laksana, A. A. N. P. (2019). The effect of the dominant muscle strength and self confidence on the results climb of the rock climbing,' $\mathrm{s}$ athlete. Jurnal SPORTIF: Jurnal Penelitian Pembelajaran, 5(1), 124-139.

Hayakawa, K., \& Kobayashi, K. (2011). Physical and motor skill training for children with intellectual disabilities. 
Perceptual and Motor Skills, 112(2), 573-580.

https://doi.org/10.2466/06.13.15.PMS.

112.2.573-580

Kesumawati, S. A., Rahayu, T., \& Dasar, M.

G. (2019). ACTIVITY MODEL OF

PLAYING ' MY HERO IS MY

MOTHER ' TO IMPROVE BASIC

MOVEMENT SKILLS OF MILD

MENTAL RETARDED CHILDREN. 4(1), 52-61.

Lancioni, G. E., Singh, N. N., O'Reilly, M. F., Sigafoos, J., Alberti, G., Perilli, V., Zimbaro, C., Boccasini, A., Mazzola, C., \& Russo, R. (2018). Promoting physical activity in people with intellectual and multiple disabilities through a basic technology-aided program. Journal of Intellectual Disabilities, 22(2), 113-124. https://doi.org/10.1177/174462951668 4986

Lohrmann, D. K. (2012). Intervention on Physical Activity Knowledge and Intellectual Disabilities. 26(5), 313317.

Martinus, M., \& Kesumawati, S. A. (2020). PELAKSANAAN PERMAINAN GERAK DASAR MANIPULATIF PADA ANAK TUNAGRAHITA DI SDLB C KOTA PALEMBANG. Kinestetik: Jurnal Ilmiah Pendidikan Jasmani, 4(1), 117-121.

Nurbani, N. (2020). PEMBELAJARAN OLAHRAGA PERMAINAN BOCCE UNTUK MENGEMBANGKAN DAN MELATIH GROSS MOTOR SKILLS PADA SISWA TUNAGRAHITA SEDANG. INCLUSIVE: Journal of Special Education, 5(1).

Payne, V. G. (2017). Human Motor Development. In Human Motor Development. https://doi.org/10.4324/978131521304 0
Atesya, Selvi K, Ambri, S Damanik. (2019). Model Pembelajaran Gerak Dasar Pada Anak Tunagrahita Ringan.Jurnal Ilmu Keolahragaan Vol 18(2), 146153. - ISSN: 1693-1475, e- ISSN: 2549-9777.

Zikl, P., Holoubková, N., Karásková, H., \& Veselíková, T. B. (2013). Gross Motor Skills of Children with Mild Intellectual Disabilities. International Journal of Social, Behavioral, Educational, Economic, Business and Industrial Engineering, 7(10), 27892795. 